\title{
eLyra
}

\section{Real e realidades híbridas: Herberto Helder entre a pedagogia e o crime}

\author{
Ana Cristina Joaquim \\ Universidade Estadual de Campinas - Unicamp
}

Resumo: A partir de uma problematização dos limites dos gêneros e subgêneros discursivos, este ensaio levanta algumas questões acerca do estatuto que a noção de representação desempenha em Herberto Helder. Com o objetivo de situar a sua posição literária numa discussão contemporânea mais abrangente, que possa sondar as implicações éticas subjacentes a uma não planificação da realidade - em termos pedagógicos -, tomo como mote uma leitura de "Aprender ou Não", crônica jornalística escrita em 1971, postumamente publicada em livro.

Palavras-chave: Herberto Helder, poesia, prosa, representação, crime

\begin{abstract}
Starting from a problematization of the discursive genres and subgenres limits, this essay raises some questions about the status the notion of representation plays in Herberto Helder. In order to situate his literary position in face to the broadly contemporary discussion, capable of probing the ethical implications underlying a non-homogeneous reality - in pedagogical terms -, I take as a motto a reading of "Aprender ou Não" (which means "To Learn or Not"), a journalistic chronicle written in 1971, posthumously published in book.
\end{abstract}

Keywords: Herberto Helder, poetry, prose, representation, crime 
De agora em diante, você chamará poema uma certa paixão de marca singular, da assinatura que repete sua dispersão, a cada vez, além do logos, a-humana, dificilmente doméstica, nem mesmo reapropriável na família do sujeito: um animal convertido, enrolado em bola, voltado para o outro e para si, uma coisa em suma, modesta, discreta, próxima da terra, a humildade a que você dá um sobrenome, transportando-se com isso ao nome para além do nome, um ouriço catacrético, todas as flechas para fora, quando esse cego sem idade ouve mas não vê a morte vir.

Jaques Derrida

[...] Terás, pois, de tudo aprender:

o coração inabalável da verdade fidedigna

e as crenças dos mortais, em que não há confiança genuína.

Parmênides

\section{Apresentação}

Não me contes nenhuma história. Eu é que conto. Era um homem verde que ia por um caminho verde até a um cais verde e depois meteu-se num barco verde e ia para um lugar verde.

Palavra de honra que isso é verdade. Passou-se entre mim e uma criança de cinco anos [...]. (Helder 2018: 44)

Esse trecho inicia o texto "Aprender ou não", uma das crônicas que Herberto Helder escreveu para o Notícia - Semanário Ilustrado, durante o período em que viveu em Luanda e trabalhou como jornalista, a despeito do desprezo que nutria pelo ofício, que ironiza fortemente em "Maiúsculas e Minúsculas" (outra crônica do mesmo período): "Toda a gente escrevia da mesma maneira sobre os mesmos temas. A rapaziada triunfava" (idem: 36). 
Adiante voltarei ao alvo dessa ironia. Por agora, importa pensar os termos dessa relação entre o autor da crônica e a criança de cinco anos. Trata-se de perceber o modo como se desestabilizam as ideias tradicionalmente propagadas de representação e de fronteiras discursivas em favor de uma escrita híbrida que valoriza a inventividade como sentido inaugural. Acredito que pensar em representação, real e fronteiras discursivas (ou em sua flexibilização: hibridismos) como noções interdependentes ajuda a entender as tensões que cercam o lugar literário na contemporaneidade, e talvez esclareça alguns aspectos sobre o modo singular como $\mathrm{HH}$, apesar de todas as suspeitas, se faz contemporâneo. Com esse objetivo, tratarei de situar a questão a partir de reflexões contemporâneas acerca do estatuto da poesia e de sua flexibilização enquanto discursividade híbrida (Agamben 2002, Siscar 2016) e, simultaneamente, de algumas reflexões acerca do estatuto ético da escrita (Agamben 1993, Bataille 1957) que possibilitaria repensar a pedagogia nos termos de uma desmontagem (tal como proposta por Herberto Helder), da qual faz parte também uma reflexão sobre o crime à qual me atenho, presentemente, apenas como sugestão de desdobramento possível.

"Palavra de honra que isso é verdade", afirma Herberto Helder. Como se ele mesmo estivesse a expressar certa admiração incrédula? Como se, por meio dessa inscrição do pacto de sinceridade, ele objetivasse garantir textualmente ao leitor a verdade fatual do evento que motivou o relato - no caso, o diálogo com a criança? Ou será que a verdade fatual do evento está na relação direta que o termo verdade tem com os termos narrativamente associados: homem verde, caminho verde, cais verde, barco verde, lugar verde? Neste último caso, a exigência que se faz ao leitor é levada às últimas consequências - Helder exige que sejamos cúmplices, ao seu lado (ele próprio cúmplice), do crime cometido pela criança de cinco anos: é preciso compactuar com a realidade desse homem verde e de seu percurso no cenário verde. No entanto, por que seria criminosa essa narrativa infantil?

Essas questões merecem atenção, pois permitem perceber as problematizações que sua poética levanta como contributo para a contemporaneidade, em um sentido em especial: o investimento que fazemos, enquanto seres sociais, numa determinada forma de organizar os elementos da nossa percepção sem que isso venha a desestabilizar certa 
harmonia - a modalização é necessária - no convívio entre os indivíduos. Essa organização ocorre sobretudo como ordenação (exigência do cumprimento da organização mesma), ainda que a ordem dada seja, atualmente, diluída em dispositivos que nem sempre coincidem com uma voz ordenadora, localizada, em relação à qual poderíamos eventualmente negociar de maneira direta. Fato é que a ordem se confirma na capacidade que temos de nos reconhecer - fenomenologicamente e, portanto, ontologicamente e esteticamente, mas também moralmente e politicamente - numa determinada representação da realidade e na capacidade que desenvolvemos (tanto quanto "somos desenvolvidos") de conhecer o mundo a partir dela. Isso ocorre, pois partilhamos, todos, como indivíduos socialmente integrados - de forma tão imperativa quanto vaga (ou de difícil definição) - dessa larga estrutura a que chamamos o real.

O que eu gostaria de enfatizar é que a ordem se confirma também a respeito do modo como se determinam as práticas de escrita, mais particularmente, sobre o modo como se circunscrevem os gêneros e subgêneros da literatura. Assim, um texto que se apresenta como prosa ou um texto que se apresenta como poema cria no leitor as expectativas de recepção próprias associadas às respectivas formas de organização textual. Seria incorrer em ingenuidade acreditar que as formas literárias não compõem o escopo do que chamamos 0 real. Elas sequer existiriam e, no entanto, existem: como convenção e como instituição, das quais participa não apenas a publicação da obra em si, mas a situação pública da fala autoral alinhada mediante pronunciamentos em jornais, entrevistas (ou, como é o caso de Herberto Helder, mediante a recusa a dar entrevistas), correspondências, premiações etc. (cf. Siscar 2016). A partir do momento em que se fazem frequentes os debates acerca das formas híbridas - conforme ocorre contemporaneamente, como tentativa crítica de criar ferramentas de leitura que estejam mais aptas para dialogar com os objetos artísticos que nos são apresentados -, somos novamente desafiados diante do fato de que os modos de organizar a realidade não são estáticos.

Apesar desses debates acerca do hibridismo serem cada vez mais frequentes na crítica contemporânea, também é perceptível que atualmente fala-se muito em escrita híbrida para qualificar qualquer texto sobre o qual não seja possível fixar o rótulo de sua filiação genética em termos de gêneros discursivos (poema, conto, novela, drama, romance, 
crônica, etc.), de modo que essa qualificação vem acompanhada de uma tendência a encerrar a questão por meio do próprio qualificativo. Acredito, entretanto, que seja produtivo ir além do fechamento decorrente do pacto imediato com o hibridismo, para que seja possível sondar os modos como esse procedimento ocorre na atualização discursiva de Herberto Helder, bem como as consequências que isso gera em termos de uma política literária própria à contemporaneidade - política essa na qual estaria incluído, além de um novo pacto entre emissor e receptor, também um elemento de transposição entre os termos que condicionam a inscrição e a excrição literárias (assim grafados para destacar as propriedades da literatura em relação, respectivamente, aos elementos característicos da fundação de uma sintaxe e ao modo como a literatura se realiza, o que seria o mesmo dizer: em relação ao modo como a literatura compõe realidades).

\section{O poeta, o prosador}

A respeito dos hibridismos, Marcos Siscar, num texto em que se dedica a pensar a figura da prosa nos interstícios da poesia, demonstra inquietação com as formas de abordagem que encerram o debate afirmando tão sucintamente o relativismo poético, na esteira de uma ideia mais ou menos cristalizada de corrosão contemporânea de qualquer proposição sobre a poesia:

\footnotetext{
Embora evidentemente haja um deslocamento em relação ao modo como, no passado, eram feitas determinadas totalizações interpretativas, ao invés de pensar em termos de esgotamento, preferiria constatar que essas manifestações (de debate e de embate) constituem a camada mais interessante e mais interessada da poesia atual [grifo meu], preocupada sobretudo com o efeito "político" de seus gestos. (Siscar 2016: 176)
}

Não é aleatória a escolha do trecho supracitado: penso que no caso de Herberto Helder a poesia é sempre a pedra de toque de que devemos nos servir para lidar com a sua maneira de dar forma ao hibridismo. É importante destacar que o foco deste ensaio são os textos em "prosa", não versificados, e supô-los "prosa" se justifica, se pensarmos de maneira bastante vaga na delimitação do poema, enquanto gênero, como questão formal; mas não se justifica, se pensarmos na delimitação do poema, com Agamben, enquanto enjambement, isto é, de um ponto de vista mais filosófico, enquanto "tensão e contraste [...] entre o som e 
o sentido, entre a série semiótica e a série semântica" (Agamben 2002: 143), ou seja, enquanto essa espécie de abrangência de que os sentidos semiótico e semântico se compõem na fricção de seu enlace. Portanto, sem qualificar categoricamente (ou tradicionalmente) os textos que estarão em evidência neste ensaio, direciono a atenção notadamente a passagens de algumas crônicas postumamente reunidas em livro, e a passagens de Os Passos em Volta e de Photomaton \& Vox.

Herberto Helder é sobretudo conhecido como poeta, não apenas porque grande parte do que escreveu foi publicado sob a diretriz poética (poemas, ou um único poema contínuo), mas também por tornar a poesia um mote da sua "prosa". Creio que seria possível afirmar que HH sugere o desejo de que seus textos não incluídos nas recolhas poéticas sejam lidos como espécie de glosa, no sentido mesmo que o termo adquire literariamente: variações do mote, variações em torno da ideia de poema, ou: de uma específica ideia do que seria o poema, o propriamente poético.

N’Os Passos em Volta, livro que reúne textos que tenderíamos a encerrar sob a alcunha de contos, há muitos momentos em que a poesia aparece tematizada no centro do percurso. Menciono apenas duas passagens em que isto ocorre: "Não descuido a minha obra. Deve-se velar por aquilo que conseguiu ascender, entre riscos e ameaças, às condições da realidade. Mas serão os meus poemas uma realidade concreta no meio das paisagens interiores e exteriores?" (Helder 2005: 115); assim também em "Poeta Obscuro": "Escrevo o poema - linha após linha, em redor de um pesadelo do desejo, um movimento da treva, e o brilho sombrio da minha vida parece ganhar uma unidade onde tudo se confirma: o tempo e as coisas" (idem: 133). Sobre o livro, Luís Mourão afirma: "No movimento interno da obra em prosa, a figura do poeta canibaliza a figura do autor" (Mourão 2015: 169). Também Manuel de Freitas vai considerar a questão em consonância com a posição expressa por Herberto Helder (conforme exposto mais adiante): "pode-se até afirmar, com inteira legitimidade, que Herberto Helder nunca escreveu prosa" (Freitas 2012: 97). Ruy Belo diz que Herberto Helder proclama o "princípio da equivalência de todos os processos estéticos." (Belo 2002: 188), o que permite inclusive a referência ao seu modo de criar um cinema das palavras: “Qualquer poema é um filme” (Helder 2013: 141), defende Helder, enfatizando a 
ideia de imagem, montagem e temporalidade poéticas, conforme os desdobramentos críticos em Rosa Maria Martelo (cf. 2012a) e em Rita Novas Miranda (cf. 2019).

Isso parece aplicar-se especialmente ao caso de Photomaton \& Vox, livro a propósito do qual Maurício Salles Vasconcelos diz o seguinte:

Único livro em que Herberto Helder reúne textos sobre estética, propício ao estabelecimento de uma poética, Photomaton \& Vox se mostra inseparável da escrita de poemas (em versos e em prosa) assim como das referências feitas pelo autor ao seu projeto e itinerário criativos. O livro se compõe, também, da mescla com inserts biográficos e notas sobre história, ou melhor, sobre o seu modo de acontecer na perspectiva do laboratório fotomático-vocal instalado no interior da lírica portuguesa por Helder, desde os fins dos anos de 1950. (Vasconcelos 2015: 139)

É, aliás, em Photomaton \& Vox que Herberto Helder se pronuncia com mais veemência: "Não nos acercamos da prosa, a prosa não existe, a prosa é uma instância degradada do poema, a prosa não presume uma qualidade de visão e execução" (Helder 2013: 140).

As aspas que acompanham o termo "prosa", conforme eu grafei mais acima, são já uma problematização no sentido dos hibridismos acolhidos na sua escrita. Em entrevista concedida a Fernando Ribeiro de Mello, Herberto Helder responde, a propósito de Os Passos em Volta:

Esse livro pertence ao mesmo sistema de propostas e soluções dos outros. Inscrevê-lo na designação de contos, ou chamar aos meus outros livros conjuntos de poemas, significa apenas ausência de superfície às categorias estabelecidas. Não me parece necessário referir a crise das classificações literárias. Caminha-se, sabemo-lo todos, para uma visão total da obra literária que se [sic] não podem adoptar distinções afinal nunca rigorosas, senão de um ponto de vista didáctico e, assim mesmo, somente em determinado grau de didactismo, Os Passos em Volta são a minha primeira tentativa para superar a dicotomia prosa-poesia. (Helder/Mello 1964: s.p.)

Essa posição aparece em entrevista do mesmo período concedida a Maria Augusta Seixas: 
Estou a pensar na crise do verso como unidade rítmica e visual do poema, e penso também na decadência da ficção "realista", por outro lado [...]. O rigor da distinção entre poesia e prosa começa a correr o risco de se tornar um pequeno prazer académico e erudito. (Helder/Seixas 1964: 10)

É também por meio de uma entrevista (nesse caso uma autoentrevista primeiramente publicada em 1987) que Herberto Helder vai reafirmar: "Não existe prosa. A menos que se refiram a escritos, em prosa ou verso, que pretendem ensinar. Não há nada a ensinar embora haja tudo a aprender" (Helder 2001: 195).

Antes de tratar da dimensão pedagógica que Herberto Helder defende ser tarefa da prosa (conforme sua concepção de prosa), importa tratar do modo como a poesia consegue ascender [...] às condições de realidade. Num certo sentido, o que está em jogo são as questões lançadas nas entrelinhas: o que é a realidade? De que modo a poesia se relaciona com a realidade? Questões que o próprio HH apresenta, ora de forma ironicamente indagativa: "Olha, olha: eles sabem o que é a realidade! Pergunto onde aprenderam, que eles são dos que aprendem. Meninos, onde está afixado o cartaz: ISTO É A REALIDADE - ?" (Helder 2013: 116), ora de forma francamente indagativa: “(O poema é a criação do eu, do real. § Ou a confirmação? Ou a transgressão? Ou a refutação?)" (idem: 136).

Questões às quais o próprio Herberto Helder responde incansavelmente, de maneira oscilante: ora de forma bastante assertiva - "O que os poetas provam é que é preciso uma imagem para revelar que a realidade não existe" (idem: 57), ou: "O mundo é linguagem como invenção" (idem: 138), ou: "A poesia propõe a história do mundo" (idem: 144); ora de forma metaléptica: "O propósito do poema é esclarecer-se a si mesmo e nesse esclarecimento tornar viva a experiência de que é o apuramento e a intensificação" (idem: 137), ou: “(A respeito da poesia pode ainda dizer-se: - A lâmpada acesa faz com que se veja a própria lâmpada)" (idem: 136), e ainda:

A escrita representa-se a si, e a sua razão está em dar razão às inspirações reais que evoca.

E produz uma tensão muito mais fundamental do que a realidade. É nessa tensão real criada em escrita que a realidade se faz. O ofuscante poder da escrita é possuir um poder de persuasão e violentação de que a coisa real se encontra subtraída. (idem: 54 ) 
A metalepse, como forma de resposta recorrente, parece se ocupar justamente de uma hesitação em que se mantém a tensão entre o que seria próprio à poesia e o que seria comum à não poesia (note-se que Herberto Helder nem sempre se limita aos vocábulos poema e poesia: fala também em imagem, linguagem, escrita, ampliando ainda mais a gama dos hibridismos perseguidos). Não creio, entretanto, que, naquilo que poderia eventualmente ser situado no escopo do que seria comum à não poesia, poderíamos elencar a prosa. Ao menos, não uma ideia de prosa que tenha por definição a disposição formal das palavras, tampouco o caráter narrativo como modo de dar forma temática ao tema. Por outro lado, suspeito que uma ideia de prosa que preveja o ensino como imperativo moral estaria fora do escopo da ideia de poesia que defende Herberto Helder e da qual é partidário, mesmo quando não escreve versos e/ou conta estórias. Nesse contexto de enunciação, seriam didáticos todos os procedimentos ideológicos a que a escrita se filia visando a doutrinação. Caberia, é claro, nos perguntarmos pelos limites (também aqui) que encerram a ideia de doutrinação. Conviria lançar a questão: em que medida Herberto Helder seria ou não doutrinário - à maneira dos vanguardistas - ao dizer a que veio?

Mais imediatamente, retomo a reflexão acerca da metalepse e noto que, conforme um dos modos de sua manifestação literária, é possível conferir a essa figura o atributo de "transformer les poètes en héros des faits qu'ils célèbrent, les représenter comme opérant eux-mêmes les effets qu'ils peignent ou chantent" (Fontanier 1967: 116) [transformar os poetas nos heróis dos fatos que eles celebram, representá-los como conduzindo, eles mesmos, os efeitos que eles pintam ou cantam]. O poeta, assim, "est représenté ou se représente comme produisant lui-même ce qu'il ne fait, au fond, que raconter ou décrire" (Fontanier 1968: 128) [é representado ou se representa como produtor, ele mesmo, daquilo que ele não faz, de fato, senão contar ou descrever]. A metalepse é um dispositivo que apresenta uma grande abrangência em termos de potência analítica; ${ }^{1}$ entretanto, a atenção que dá Fontanier a essa espécie de mise en abîme das fronteiras implicadas na ideia de representação (o poeta e o poema, ambos "representados" no momento coincidente de sua "apresentação") me interessa particularmente no caso de situar a práxis poética de Herberto Helder. ${ }^{2}$ Com esse objetivo, gostaria, ainda uma vez, de enfatizar um dado dessa poética: 
nela, a poesia é realidade, ou: a realidade é evidenciada no seu potencial infinitamente abrangente. Novamente, o assunto é motivo da invenção:

(escrita pouco inocente)
[...]
Os poetas são metafísicos.

Não.

A metafísica é uma distância de onde os poetas vêem, em perspectiva, a realidade.

Não.

Não há realidade?

Não, não há realidade - todos os poetas são claros a esse respeito.

Se eles dizem - atenção - cria-se a realidade da atenção.

Se eles dizem - atenção - anulam a atenção, criam um espaço vazio. (Helder 2013: 57)

Seria o mesmo que dizer que o real não é algo que se possa ensinar, pois aquilo mesmo que seria o real coloca uma série de questões - que devem ser direcionadas a certo ponto de vista bastante difundido (embora não estabilizado consensualmente na arrogância hierarquizante que o sustenta); tanto quanto a poesia o faz, conforme atenta Marcos Siscar: questões que "aponta[m] para [o hibridismo], ao colocar em primeiro plano a difícil questão de seus limites, de suas margens; ou seja, no fundo, a questão de seu 'outro'” (2016: 163). De um autor que defende a experiência e a experimentação, como é o caso de Herberto Helder, importa pensar que o hibridismo a que nos lança ultrapassa as categorizações literárias para levantar a questão da representação: é o próprio hibridismo do real que parece estar em evidência, o hibridismo essencial ao discurso humano; a percepção como vir a ser, em sua iminência ou em seu movimento contínuo: poema.

\section{(Est)ética}

Em resposta ao inquérito posto na quinta edição da revista $O$ Tempo e o Modo - uma publicação com forte teor militante, que teve vida ativa durante o Estado Novo e cujo número em questão "foi submetido a censura prévia", conforme somos informados na subscrição -, Herberto Helder é bastante enfático quanto a esse hibridismo de partida, e fala, sobretudo, a respeito do estatuto da poesia: 
1. Qual o modo mais fecundo de o Poeta colaborar na Cidade?

$[\mathrm{HH}]$ Escrever poemas.

2. A imposição de uma orientação ideológica (de qualquer caráter, moral, político, religioso) não será uma limitação da liberdade do poeta?

[HH] Parece-me evidente. E a propósito: a Poesia é a liberdade do poeta; a Poesia é a limitação do Poeta.

3. Só se poderá considerar social a poesia que cante as inquietações de valor sócio-político, ou possui interesse verdadeiramente social toda a poesia que cante o homem sem qualquer limitação de temas? [HH] Só existe um tema para o poeta: a sua experiência. Não há experiência pessoal que não seja experiência social. (Helder 1963: s/p)

O estatuto da poesia como componente social, aqui entendida na chave da recusa de uma certa modernidade (a mallarmaica), porque defende a hiper-realização determinada pela aposta da poesia como experiência - enquanto a modernidade referida seria responsável pela disseminação da ideia de poesia pura ou absoluta e, consequentemente, de desrealização -, é uma tomada de posição que reacende os debates acerca da definição do real e que tem consequências na ideia de representação. Sem dúvida trata-se de uma posição política (enfatizada pelo contexto específico de sua publicação), naquilo que em política é devido a uma preocupação ética, que não deve ser confundida com qualquer orientação ideológica de caráter moral. Acredito que nos indagar acerca do norteamento ético da escrita como atividade importa para que seja possível nos pensarmos, contemporaneamente, enquanto seres em atividade, supondo, da atividade, o caráter de movência que ela comporta:

O facto de onde deve partir todo o discurso sobre ética é de que o homem não é nem terá de ser ou de realizar nenhuma essência, nenhuma vocação histórica ou espiritual, nenhum destino biológico. É a única razão por que algo como uma ética pode existir: pois é evidente que se o homem fosse ou tivesse de ser esta ou aquela substância, este ou aquele destino, não existiria nenhuma experiência ética possível - haveria apenas deveres a realizar. (Agamben 1993: 38)

Conceber uma existência ética que seja capaz de romper com os imperativos (sob diretriz moral) que classicamente lhe conferem estatuto é uma questão pedagógica? É uma questão de aprendizado quotidiano, suponho; no entanto, eu não saberia precisar quanto 
desse aprendizado se faria refém de alguma doutrina (p. ex.: a doutrina que defende o acolhimento da metamorfose como princípio definidor do real).

"Aprender ou não" é o título da crônica em que Herberto Helder se dedica, portanto, a problematizar a abordagem pedagógica destinada ao ensino: “Muita da nossa pedagogia a mais tradicionalista, pelo menos - parece destinar-se a converter a criança à sabedoria ignorante que trata das coisas e loisas, por entre as quais se há-de mover a frenética ocupação dos nossos dias tristes, estéreis" (Helder 2018: 45). Mas também é o nome da crônica em que Herberto Helder se dedica a pensar a invenção, o perigo, a verossimilhança.

Partindo de "meia dúzia de palavras fulminantes" (idem: 44) escritas, nostalgicamente, por Fernando Pessoa ("Fui feliz? Fui-o outrora agora"), Herberto Helder conclui que o adulto, quando inventa, está necessariamente a inventar a "infância como terapêutica de ser adulto" (idem: 45), pois a invenção é capacidade exclusiva das crianças, que "introduz-se nos adultos através de fendas nos granitos da razão e da utilidade" (idem: 46). Quase como se estivesse a parafrasear Georges Bataille: "Ce que la société oppose au libre jeu de la naïveté est la raison fondée sur le calcul de l'intérêt"' (Bataille 1957: 16) [O que a sociedade opõe ao livre jogo da ingenuidade é a razão fundada sobre o cálculo do interesse]. Inclusive, no fim da crônica, ao modalizar o elogio ilimitado à potência infantil:

Devemos evitar que as crianças cometam, pelo menos, todos os crimes que têm na cabeça. Seriam os mais pavorosos (e os mais interessantes, também) da História Universal. Deixemos que elas cresçam, para então exercerem, com alguma moderação e senso de oportunidade, o seu prolixo talento criminal.

Aqui reside o pouco que lhes podemos ensinar. No mais, nada há a fazer senão receber suas lições. Venham a nós criancinhas. (Helder 2018: 49) ${ }^{3}$

Momento em que se mostra atento ao pacto consensual para que o mundo se faça partilha possível, novamente conforme Bataille:

La société s'ordonne de manière à en rendre possible la durée. La société ne pourrait vivre si s'imposait la souveraineté de ces mouvements primesautiers de l'enfance, qui avaient lié les enfants dans un sentiment de complicité. La contrainte sociale aurait demandé aux jeunes sauvages d'abandonner leurs souveraineté naïve, elle leurs aurait demandé de se plier aux raisonnables 
conventions des adultes: raisonnables, calculés de telle façon que l'avantage de la collectivité en résulte. (Bataille 1957: 16)

[A sociedade se ordena de maneira a possibilitar a duração. A sociedade não poderia viver caso se impusesse a soberania desses movimentos impulsivos da infância, que vincularam as crianças mediante um sentimento de cumplicidade. A restrição social exigiu que os jovens selvagens abandonassem a sua soberania ingênua, ela exigiu que eles se dobrassem às razoáveis convenções dos adultos: razoáveis, calculadas de tal maneira, que o benefício em favor da coletividade se torna possível.]

Nessa crônica, não sem alguma pedagogia - com foco no aprendizado, mais do que no ensino -, Herberto Helder se dispõe a enfrentar a difícil conjunção entre a soberania primordial infantil (própria à inventividade) e as razoáveis e calculadas convenções dos adultos (próprias ao benefício da sociedade). Ele não deixa de enfrentar também a questão discursiva como difícil conjunção que, por sua vez, ocorre entre o didatismo que uma crônica jornalística exige, como gênero, e a própria dificuldade em pactuar com um jornalismo pouco inventivo, que careceria desse impulso inaugural que a (invenção da) infância possibilitaria, conforme trecho de outra crônica que retomo para o presente propósito de dar a ver essa espécie de crime: "Toda a gente escrevia da mesma maneira sobre os mesmos temas" (Helder 2018: 36). A maneira mesma e os temas mesmos são uma crítica à reprodução da linguagem sem que nela sejam impressos os traços que a poderiam diferenciar, aquilo que poderia torná-la híbrida, outra de si mesma, potencializando o seu uso mediante o que seria o próprio poético (sem que essa particularidade se confunda com o absoluto poético ou o puro poético, uma vez que a questão parece incidir muito mais no que respeita a uma ética implicada na forma do dizer do que a uma estética - que estaria implicada no formalismo do dizer). A crítica direcionada aos jornalistas é irônica: "A rapaziada triunfava" (ibidem), e envolve justamente uma crítica da representação: reproduzir a linguagem ou representá-la - conforme se reproduz uma certa ideia de realidade ou se representa a realidade - a partir de uma ideia pré-concebida do que seria $o$ comum num uso da linguagem à maneira de um jornalista (o que equivaleria a dizer: à maneira de todos os jornalistas). 


\section{A realidade, o verossímil}

Ao colocar em crise a ideia de representação, Herberto Helder não pode se furtar a estabelecer, ele próprio, uma teoria da verossimilhança: o adulto inventa a infância como terapêutica de ser adulto, e continua: "Não é ela invenção que parta de coisa nenhuma. Assegura-Ihe a verossimilhança um fundamento bem real [grifo meu]: numa certa perspectiva (que, não raro, é uma perspectiva certa), a criança sabe exactamente o que o adulto ignora" (idem: 45). Ainda nessa mesma crônica, Herberto Helder vai além: "se nos dermos a analisar o que dizem as crianças, ver-se-á que ao seu delicioso nonsense preside uma legislação lógica, um princípio de coerência interna" que, por finalidade, teria “[modificar] a realidade segundo o princípio do desejo. E isto é não só o princípio mesmo da poesia, mas o das relações do homem com a realidade - o significado do trabalho criador. Adaptar o mundo ao nosso desejo, através de um acto radical" (idem: 47). Através de um ato criminoso?

Acredito que seja possível dizer, não sem alguma ressalva - porém contra Herberto Helder (embora bem acompanhada) -, que a teoria helderiana da verosimilhança não se distanciaria tão inteiramente da teoria aristotélica, conforme defende Pedro Eiras, a respeito de um texto bastante conhecido de Photomaton \& Vox, em que discorre sobre a recusa helderiana da ideia de mimesis:

Podemos concluir que a sugestão herbertiana não faz justiça à argumentação de Aristóteles? A infidelidade de "(a paisagem é um ponto de vista)" tem, é claro, uma função; "Desde que se assegurou aristotelicamente a arte imitar a natureza" é uma expressão (argutamente) falaciosa. (Eiras 2005: $167)^{4}$

Herberto Helder, ao dizer que entre as crianças preside uma legislação lógica, um princípio de coerência interna, não seria assim tão contrário à ideia aristotélica que define a verosimilhança como aquilo que seria semelhante à verdade, isto é, como filiação criativa às possibilidades reais do homem agir no mundo. Claro esteja que as ideias em torno do que seria agir e do que seria mundo não pararam de se metamorfosear de Aristóteles a Helder. A ponto de Herberto Helder reter apenas a metamorfose como princípio universal, única fidelidade possível, conforme diz em "Teoria das cores" (infra). 
É mesmo de experiência que se trata - a escrita ou o real, termos que, acredito, ganham força argumentativa se usados como sinônimos -, conforme também Luis Maffei está atento, ao discorrer sobre a escola da leveza ou a escola da laranja (cf. Maffei 2018: 1), a propósito de um poema de A Faca não Corta o Fogo em que a experiência é insistentemente convocada à cena poética mediante o foco na percepção sensorial. Note-se o apelo ao tato e ao paladar neste fragmento:

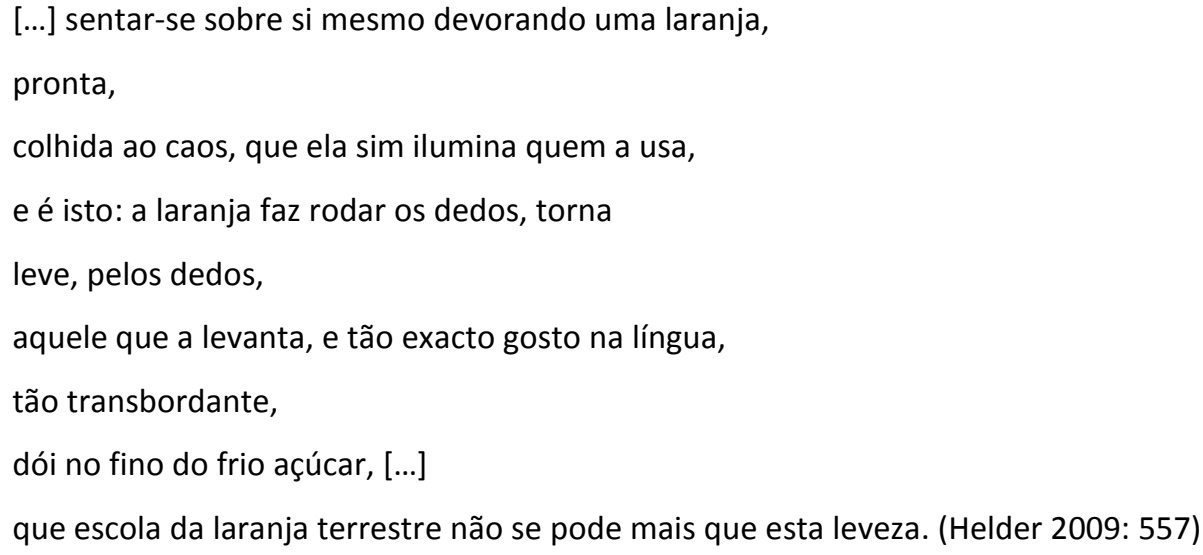

Em "Teoria das cores", é à visão e ao movimento que se apela: "Era uma vez um pintor que tinha um aquário com um peixe vermelho. Vivia o peixe tranquilamente acompanhado pela sua cor vermelha até que principiou a tornar-se negro a partir de dentro, um nó preto atrás da cor encarnada". O pintor, que, entretanto, "não sabia o que fazer da cor preta que [o peixe] agora Ihe ensinava", resolveu pintar um peixe amarelo, depois de compreender a lei que o peixe lhe ensinava, uma lei que abrange "tanto o mundo das coisas como o da imaginação. Era a lei da metamorfose." (Helder 2005: 21-22) Consideremos, ainda, o excerto da "crônica" "Aprender ou Não", em que toda a narrativa da criança é tingida de verde (Palavra de honra que isso é verdade).

Trata-se, assim, de uma escola em que a laranja, o peixe e a criança ensinam sobre a invenção pela experiência, ou, metalepticamente, sobre a experiência pela invenção, uma vez que o que se ganha com essa poética é a possibilidade de romper com o condicionamento em relação à linearidade. Não é a linearidade um dos atributos do que, com um certo consenso, ${ }^{5}$ entendemos por real? O próprio real é mise en abîme, para não dizer somente que o real é ele próprio o abîme. 
Arrisco dizer que é ainda sobre a infância uma crônica intitulada "Outros Tempos, Outras Gentes", um elogio ao continente africano (“Hoje, a aposta jovem chama-se África”), em que se faz uma crítica à velhice como momento da existência "que se faz obstáculo ao dinamismo natural da vida" - novamente se contrapondo a uma ideia de realidade estática, novamente em defesa da metamorfose:

O mal das sociedades que se orgulham de uma grande tradição cultural é que supõem haver encontrado forma definitiva de resolver os problemas todos. Passa-lhes desapercebida a qualidade dinâmica da realidade e a exigência que esse mesmo dinamismo tem de instrumento, que da tradição apenas aproveitem aquilo que não morreu e que normalmente é menos do que se pensa. (Helder 2018: 105)

\section{Não conspirem contra infâncias}

Silvina Rodrigues Lopes elabora reflexão relevante acerca da infância em Herberto Helder:

[...] em Herberto Helder [o retorno do diferente] corresponde ao devir-criança, que não é o representar-se à imagem de uma criança, ou de uma infância da humanidade, mas o tocar aquele momento inicial onde a natureza brota na sua separação e é sensível como um grito, o tocar a natureza nesse grito que sempre se ouve na distância e que torna o corpo excessivo e aberto. (Lopes 2009: 174)

O sentido inaugural presente nessa reflexão, claramente ligado ao ofício criativo, é consoante ao modo propriamente poético como Herberto Helder se faz cronista. É também poético - se pudermos definir como poético, em $\mathrm{HH}$, tudo o que se filia ao real (aqui entendido como o escopo das metamorfoses em curso, ou das metamorfoses possíveis) - o gesto de constante reapropriação e modificação da escrita. Por exemplo, neste caso já mencionado (com outros propósitos) ao qual se refere Pedro Eiras: "intitulando-se '( $a$ paisagem é um ponto de vista)', entre parêntesis e em itálico, sublinhando a parergonalidade dos títulos (cf. Derrida: 1978) em relação aos textos propriamente ditos de Photomaton \& Vox" (Eiras 2005: 153). ${ }^{6}$ É aliás híbrido o jogo que se propõe parergonal, que 
situa a escrita entre ausência e presença, o "fora da obra", o suplemento que projeta-se a partir daquilo que se apresenta como potência relacional e cria continuidades.

Penso que a difícil tarefa de recusar as oposições que imobilizam aquilo que seria $o$ próprio poético (sem incorrer numa defesa, tão assertiva quanto lacônica, do relativismo poético) é uma das maneiras de dar forma ao debate acerca do hibridismo. Eu também poderia abordar a questão, no entanto, em termos opositivos, e, nesse caso, teria de lidar com uma série de contradições. Seria um caminho interessante, permitiria desmembrar esta questão levantada por Siscar em algumas outras: "Que estatuto damos à contradição, quando lemos um poeta que a reivindica?" (Siscar 2012: 157 - nota 13). Certamente Herberto Helder estaria representado nessa indagação de partida hipotética:

A urgência da contradição mostra uma crise demasiado manifesta da cultura. A contradição conduz à linguagem sobrecarregada, alusiva, recorrente, descontínua e permanentemente incompleta. A cultura possui conotações severas, é omissa (portanto: completa). (Helder 2013: 120)

Talvez, pela contradição, a infância se explique como o mais violento de todos os crimes, uma vez que viola sua própria condição de permanência: é forçoso renunciar à metamorfose como princípio para se metamorfosear no adulto que já não se movimenta nos interstícios do real. 


\title{
NOTAS
}

\begin{abstract}
${ }^{1}$ Abrangência mais recentemente desenvolvida em estudo de Gerard Genette (cf. Genette 2004).
${ }^{2} \mathrm{~A}$ esse respeito, importa referir também o modo como Herberto Helder confunde as instâncias de enunciação e enunciador, conforme está atento Manuel Gusmão:

Como o título abre com um 'Ou' (com maiúscula inicial), os nossos hábitos linguísticos levam-nos a procurar algo que deveria estar antes: 'X ou [...]'. Ora, na 'caixa' ou no 'selo', o que vem antes é apenas o nome do Autor. Lendo assim, 'Herberto Helder' emigra da sua condição de nome de autor (que reenvia para um indivíduo humano concreto) para a condição de texto, de fragmento textual de um título. Dito de outra maneira, deixa de ser apenas o nome do poeta, do agente, para ser parte da obra. Ou ainda: "Herberto Helder é a poesia toda Ou o poema contínuo". (2010: 364)
\end{abstract}

e também Rosa Maria Martelo:

é importante acrescentar que o título Ofício Cantante tinha sido usado por Herberto Helder na primeira recolha dos seus livros de poesia, em 1967, depois da qual o poeta organizou outras recolhas, já com a inclusão de obras posteriores, sob os títulos Poesia Toda e Ou o Poema Contínuo. Lido a seguir ao nome do autor, como normalmente acontece no rosto de um livro, este último título iniciado pela disjuntiva inclusiva 'Ou' sugere uma total identificação entre o nome da obra e o nome de autor, fazendo de 'Herberto Helder' um sinónimo de 'o poema contínuo' e estabelecendo, entre ambos, um vínculo e uma permutabilidade incontornáveis. (2012b: 2)

${ }^{3}$ Em excerto de Photomaton \& Voz, intitulado "(o humor em quotidiano negro)", que reúne uma série de pequenos textos motivados por notícias de jornal, lemos: “Cinco crianças deitaram gasolina sobre um homem que dormia numa estação de autocarros, e lançaram-lhe fogo. Ficaram depois a contemplar as chamas. Disseram mais tarde que era 'belo', a coisa mais bela que tinham visto em toda a sua vida” (Helder 2013: 88).

${ }^{4}$ É de interesse acompanhar a argumentação detalhada de Pedro Eiras no ensaio em questão. Embora o motivo da problematização seja o binarismo de partida (tratamento justificado pelo excerto selecionado para leitura), o confronto inicialmente posto por Herberto Helder acerca das opções poéticas em questão (bicicleta versus helicóptero) é suavizado por uma leitura minuciosa de Eiras.

${ }^{5}$ Ainda sobre as fronteiras, acredito que seria enriquecedora uma sondagem daquilo a que chamamos loucura (a razão do[s] outro[s]?). Tema aliás bastante caro a Herberto Helder e inegavelmente uma contribuição acerca do hibridismo, não apenas pelo questionamento que levanta no que respeita aos limites de legitimidade e alcance da percepção, mas também no que respeita a uma problematização do democratismo comportamental, em que a lei da maioria acaba por turvar um debate possível, e a meu ver bastante necessário, que poderia começar por perguntar sobre as possíveis diluições (desejáveis?) das fronteiras que se estabelecem entre comunidade e singularidade.

6 “Uma primeira versão daquele texto surgiu em 1976, sem título e sem indicação do nome do autor, como introdução a uma antologia literária: Nova. Magazine de poesia e desenho, Inverno de 1975/1976" (Eiras 2005: 152). 


\section{Bibliografia}

Agamben, Giorgio (2002), “O Fim do Poema”, trad. Sérgio Alcides, Cacto, no 1, 142-149.

-- (1993), A Comunidade que Vem, trad. António Guerreiro, Lisboa, Presença.

Bataille, Georges (1957), La Littérature et le Mal, Paris, Gallimard.

Belo, Ruy (2002), "Poesia e Arte Poética em Herberto Helder”, in Na Senda da Poesia, Lisboa, Assírio \& Alvim, pp.

Derrida, Jacques (2001), “Che cos'é la Poesia?”, trad. Marcos Siscar e Tatiana Rios, Inimigo Rumor, no 10, 7 Letras/Cotovia, 113-116.

Eiras, Pedro (2005), "Scherzo com Helicópteros, a Metáfora do Voo em Herberto Helder", Revista da Faculdade de Letras. Línguas e literaturas, II Série, vol. XXII, 151-184.

Fontanier, Pierre (1968), Les Figures du Discours, Paris, Flammarion.

-- (1967), Commentaire des Tropes, Genève, Slatkine Reprints.

Freitas, Manuel de (2012), Pedacinhos de Ossos, Lisboa, Averno.

Genette, Gerard (2004), Metalepse de la Figure à la Ficcion, Paris, Seuil.

Gusmão, Manuel (2010), "Leiam Herberto Helder Ou O Poema Contínuo", in Tatuagem e Palimpsesto, Lisboa, Assírio \& Alvim, 362-366.

Helder, Herberto (2018), Em Minúsculas. Crónicas e reportagens de Herberto Helder em Angola, Porto, Porto Editora.

-- (2013), Photomaton \& Vox, Lisboa, Assírio \& Alvim.

-- (2009), Ofício Cantante, Lisboa, Assírio \& Alvim.

-- (2005), Os Passos em Volta, Rio de Janeiro, Azougue Editorial.

-- (2001), “Herberto Helder. Entrevista”, Inimigo Rumor, n.o 11, 7Letras/Cotovia, 190-197. 
-- / Fernando Ribeiro de Mello (1964), “Entrevista”, Jornal de Letras e Artes, no 139, 17 de maio, s/p <http://www.triplov.com/herberto_helder/Entrevista/index.html> (último acesso em 29/04/2019).

-- / Maria Augusta Seixas (1964), “'Não há Verdadeira Honestidade sem Alguma Originalidade' - Disse-nos Herberto Helder", Jornal de Letras e Artes, no 163, 10-12.

-- (1963), “Inquérito", o Tempo e o Modo. Revista de pensamento e acção, no 5, maio, s.p.

Lopes, Silvina Rodrigues (2009), "Investigações Poéticas do Terror", Diacrítica. Revista do Centro de Estudos Humanísticos da Universidade do Minho, no 23/3, 169-177.

Maffei, Luis (2018), "Que Poder de Ensino o destas Coisas quando em Idioma”, Translocal. Culturas contemporâneas locais e urbanas, nำ 2, 1-15.

Martelo Rosa Maria (2012a), O Cinema da Poesia, Lisboa, Assírio \& Alvim.

-- (2012b), "Herberto Helder, o nome da obra", in Quaresma, José, Gravura, Instalação e Poesia. A Alegria de um encontro, Lisboa, CIEBA-FBAUL, 44-48, <https://www.academia.edu/12440862/Herberto_Helder_o_nome_da_obra> (último acesso em 01/06/2019).

Miranda, Rita Novas (2019), Modos de Ver, Modos de Escrever. Da Imagem e da escrita em Herberto Helder e em Jean-Luc Godard, Porto, Edições Afrontamento.

Mourão, Luís (2015), “O Fim in media res ou 'Que hei-de fazer de toda a minha experiência?’ seguido de 'o universo passa bem sem mim'”, in Herberto Helder. Se Eu quisesse enlouquecia, Rio de Janeiro, Oficina Raquel, 161-173.

Parmênides (2012), Da Natureza, trad. José Gabriel Trindade dos Santos, São Paulo, Loyola.

Siscar, Marcos (2016), De Volta ao Fim. O Fim das vanguardas como questão da poesia contemporânea, Rio de Janeiro, 7Letras.

Vasconcelos, Maurício Salles (2015), Jean-Luc Godard. História(s) da literatura, Belo Horizonte, Relicário Edições. 
Ana Cristina Joaquim é Bacharel em Filosofia (Universidade São Judas Tadeu, 2008, bolseira CNpq), Licenciada em Letras (Universidade de São Paulo, 2011), Mestre em História da Filosofia (Universidade Estadual de Campinas, 2012, bolseira CNpq), Doutora em Literatura Portuguesa (Universidade de São Paulo, 2016, bolseira CAPES), e atualmente desenvolve uma pesquisa de Pós-doutoramento em Teoria Literária (Universidade Estadual de Campinas, bolseira FAPESP: 2017/17843; Faculdade de Letras da Universidade do Porto, bolseira FAPESP/BEPE: 2018/21750-1). Possui trabalhos editoriais como organizadora de antologias e prefaciadora/posfaciadora. 